\author{
International Journal of Management Science and \\ Business Administration \\ Volume6, Issue4, May 2020, Pages 42-54 \\ DOI: $10.18775 /$ ijmsba.1849-5664-5419.2014.64.1004 \\ URL: http://dx.doi.org/10.18775/ijmsba.1849-5664-5419.2014.64.1004
}

\title{
The Effect of Motivation, Emotional and Spiritual Intelligence on Lecturer Performance
}

\author{
${ }^{1}$ Rosemarie S. Njotoprajitno, ${ }^{2}$ Rully Arlan Tjahjadi, ${ }^{3}$ Nur, ${ }^{4}$ Bram Hadianto, ${ }^{5}$ Andre Sunjaya \\ 1,2,3,4,5 Management Department of Economics Faculty, Maranatha Christian University, Indonesia.
}

\begin{abstract}
Lecturers are individuals employed by the higher educational institutions to educate students based on their competency. The roles of lecturers are not limited to the education of students only but also include the activities related to the research and the service community. These three aspects are considered to be measures of lecturers' performance. Consequently, the institutions must focus on the factors behind the performance of their lecturers to increase performance. By denoting the evidence of the previous study, the three determinants of performance are identified, namely, motivation, emotional and spiritual intelligence. Therefore, this study attempts to examine and analyze these determinants in the context of private university lecturers becoming active members of the Indonesia Management Forum. To collect the data, we utilize a simple random sampling and survey method. Also, we use a variance-based structural equation as the model to analyze the attained data. Overall, this study concludes that there is a positive effect of emotional intelligence on the performance of lecturers. On the other hand, the effect of motivation and spiritual intelligence is not confirmed.
\end{abstract}

Keywords: Emotional intelligence, Lecturer performance, Higher education institution, Spiritual Intelligence

\section{Introduction}

Human resources are considered to be the main organizational assets (Gabčanová, 2011). Therefore, maintaining their commitment is mandatory for achieving excellent performance (Rishipal and Manish, 2013) and ensuring organizational success (Vosloban, 2012). Similarly, such situations can be applied to lecturers in higher educational institutions. The lecturers and their achievement will determine the quality of these institutions, (Zahraini, 2014). In Indonesia, lecturers' performance is measured by the three components, i.e., education and teaching; research, and community service (Muttaqiyathun, 2010; Pramudyo, 2010; Taruno, Thoyib, Zain, and Rahayu, 2012), and the Board of National Accreditation for Higher Education is authorized to perform the valuation for outcomes based on these three aspects.

To ensure their lecturers achieve excellent performance, the higher education institutions have to identify antecedents leading to superior performance. These include motivation (Muttaqiyathun, 2010; Pramudyo, 2010; Nur'aeni, 2011; Trisnaningsih, 2011; Taruno, Thoyib, Zain, and Rahayu, 2012; Faitullah, 2014; Anwar, 2017; Rina and Kusuma, 2017; Narasuci, Setiawan, and Noermijati, 2018), emotional (Muttaqiyathun, 2010; Faitullah, 2014), and spiritual intelligence (Muttaqiyathun, 2010; Anwar, 2017). Unlike the studies involving lecturers, some research finds that intrinsic motivation has no impact on employee performance in state-owned firms (Muogbo, 2013). Others suggest emotional intelligence decreases the enactment of the officers in educational and cultural departments (Bestyasamala, 2018), while it has previously been established that spiritual intelligence does not affect the performance of nurses (Haryono, Rosadi, and MdSaad, 2018). Based on two conflicting results, this study intends to test and analyze the effect of motivation and emotional and spiritual intelligence on the performance of lecturers.

\section{Literature Review and Hypothesis Development}

Motivation is the power to encourage employees to achieve outstanding results. Highly motivated employees can cooperate, assist, support, and inspire each other (Gibson, Ivancevich, Donnelly, and Konopaske, 2012). According to Muttaqiyatun (2010), motivation has a positive effect on lecturer performance. The result was supported by a number of studies, such as Pramudyo (2010), Nuraeni (2011), Trisaningsih (2011), Taruno et al. (2012), Faitullah (2014), Anwar (2017), Rina and Kusuma (2017), Narasuci et al. (2018). Therefore, the first hypothesis is declared as follows: 
$\mathrm{H}_{1}$ : Motivation has a positive effect on lecturer performance.

Emotional intelligence is comprised of emotional and social capabilities in all aspects of individual life (Tridhonanto and Agency, 2010). Someone who possesses and utilizes it on a daily basis will easily attain top performance (Agustian, 2007). According to Muttaqiyathun (2010) and Faitullah (2014), emotional intelligence positively influences lecturers' performance. Anwar's (2017) and Makkasau's (2018) results confirm this conclusion. Therefore, the second hypothesis is declared as follows.

$\mathrm{H}_{2}$ : Emotional intelligence will have a positive effect on lecturer performance.

Spiritual intelligence concentrates on the personality and is often associated with wisdom (Zohar and Marshall, 2007). This intelligence leads to revealing the truth, which then benefits the soul. People possessing this intelligence will achieve better performance and improve the quality of their life (Imawan, 2004). This type of intelligence contributes to performance in the face of substantial working strains because it brings about joyfulness and rationality (Noermijati, 2013). Muttaqiyathun (2010) and Makkasau (2018) support this explanation by affirming that the effect of spiritual intelligence on performance is positive. Therefore, the third hypothesis is declared as follows.

$\mathrm{H}_{3}$ : Spiritual intelligence will have a positive effect on lecturer performance.

\section{Methodology}

\subsection{Population and Samples}

The private university lecturers who have become active members of Indonesia's Management Forum before 2019 are study population. According to the information from the forum secretariat, the number of members is around 500. To get the total samples (n) that represent the total population (N), we used the Slovin formula cited in Suliyanto (2009), presented in equation 1 with the border of error (e) of $5 \%$.

$$
n=\frac{N}{1+N e^{2}}
$$

By this formula, the total samples calculated are $\frac{500}{1+500(0.05)(0.05)}=222.22 \approx 222$. To select 222 lecturers, furthermore, we utilize the simple random sampling method.

\subsection{Data Collection Method}

This research uses the primary data of respondents of the online survey carried out from March to April 2019. Unfortunately, not all respondents provided a full response. Only 100 lecturers filled the questionnaire completely. Therefore, the response rate is $100 / 222 \times 100 \%=45.05 \%$. This rate is higher than $20 \%$, which is the required response set by Sugiyanto et al. (2018). It means this level is still acceptable.

\subsection{Determining Research Variables}

The first variable is motivation, which has been measured with a scale adopted from Perwita et al. (2016) consisting of five items of intrinsic motivation (M1-M5) and extrinsic motivation (M6-M10) (see Table 1).

Table 1: Indicators of motivation

\begin{tabular}{|l|l|}
\hline The type of motivation & \multicolumn{1}{|c|}{ Indicator } \\
\hline Intrinsic motivation & M1: Working as a lecturer is interesting to me. \\
& M2: Working as a lecturer provides me with an opportunity to improve. \\
& M3: Working as a lecturer can improve my reputation. \\
& M4: Working as a lecturer encourages me to acquire some achievements. \\
& M5: Working as a lecturer stimulates me to fulfil my duties. \\
\hline Extrinsic motivation & $\begin{array}{l}\text { M6: My decision to be a lecturer is due to interpersonal relationships with other parties. } \\
\text { M7: My decision to be a lecturer is due to conducive working conditions. } \\
\text { M8: My decision to be a lecturer is due to quality supervision. } \\
\text { M9: My decision to be a lecturer is due to a clear procedure for compensation. } \\
\end{array}$ \\
& M10: My decision to be a lecturer is for adequate financial compensation. \\
\hline
\end{tabular}

Source: Adopted from Perwita et al. (2017) 
The second variable is emotional intelligence, where its measurements are denoting the study of Tjun, Setiawan, and Setiana (2017) consisting of five dimensions, namely, self-awareness (SA), self-control (SC), motivation (MOT), empathy (E), and social skills (SCL). Moreover, each indicator of these dimensions is in Table 2.

Table 2: Indicators of the dimensions of emotional intelligence

\begin{tabular}{|c|c|}
\hline Dimension & Indicator \\
\hline Self-awareness & $\begin{array}{l}\text { SA1: I like myself. } \\
\text { SA2: I know my strength. } \\
\text { SA3: I exist for a reason. } \\
\text { A4: I am angry with reason. } \\
\text { SA5: I never doubt my ability. } \\
\text { SA6: I can do something. } \\
\text { SA7: I am not worried about my future. } \\
\text { SA8: I dare to be different from my friends. } \\
\text { SA9: I can get what I want. } \\
\text { SA10: I will finish the job, although I do not like its responsibility. }\end{array}$ \\
\hline Self- control & $\begin{array}{l}\text { SC1: I am patient with other people. } \\
\text { SC2: I easily recover quickly after feeling disappointed. } \\
\text { SC3: I think of what I want before acting. } \\
\text { SC4: I remain calm in situations making other people angry. } \\
\text { SC5: I can control my life. } \\
\text { SC6: I am calmer than others. } \\
\text { SC7: I am not quickly bored and tired of doing things. } \\
\text { SC8: Tight competition does not reduce my enthusiasm. } \\
\text { SC9: To achieve another larger goal, I can delay the satisfaction of my } \\
\text { momentary pleasure. } \\
\text { SC10: I immediately finish the work I plan without wasting time. }\end{array}$ \\
\hline Motivation & $\begin{array}{l}\text { MOT1: I know the purpose of my life. } \\
\text { MOT2: I like trying new things. } \\
\text { MOT3: I always try the same job again until I am successful. } \\
\text { MOT4: I join various information and ideas. } \\
\text { MOT5: I am happy to face challenges to solve problems. } \\
\text { MOT6: If I encounter obstacles to reach a goal, I will turn to another one. } \\
\text { MOT7: I do not easily surrender when doing difficult tasks. } \\
\text { MOT8. The hope of success influences me more than the fear of failure. } \\
\text { MOT9: I am interested in work requiring me to give new ideas. } \\
\text { MOT10: I often introspect to rediscover the important one in my life. }\end{array}$ \\
\hline Empathy (E) & $\begin{array}{l}\text { E1: I own a lot of close friends from various backgrounds. } \\
\text { E2: I can usually find out how other people feel about me. } \\
\text { E3: I feel that my friend does not drop me. } \\
\text { E4: I easily understand others' point. } \\
\text { E5: I am confident when talking to people I don't know. } \\
\text { E6: I can make people I don't know talk about themselves. } \\
\text { E7: I can convey something that attracts other people's attention during the } \\
\text { meeting. } \\
\text { E8: I can feel that people are hurt, although they do not tell it. } \\
\text { E9: I am a source of advice for my friends with problems. } \\
\text { E10: I can put myself in someone else's position }\end{array}$ \\
\hline Social skills (SS) & $\begin{array}{l}\text { SS1: I can accept critiques with an open mind as long as they can be justified. } \\
\text { SS2: I easily come up with the topic of conversation with others. } \\
\text { SS3: I easily become friends with people. } \\
\text { SS4: Ethics guides me when I deal with others. } \\
\text { SS5: My problems do not affect my relationships with others. } \\
\text { SS6: I can feel the mood of a group. } \\
\text { SS7: I joy and do not talk too much when I am among people. }\end{array}$ \\
\hline
\end{tabular}

The third variable is spiritual intelligence, with indicators adopted from King (2008) as well as Anwar and Osman-Gani (2015). It covers 24 question items distributed into four dimensions: critical existential thinking (7 items), personal meaning production (5 items), transcendental awareness ( 7 items), conscious state expansion (5 items). 
Table 3: Indicators of the dimensions of spiritual intelligence

\begin{tabular}{|c|c|}
\hline Dimension & Indicator \\
\hline $\begin{array}{l}\text { Critical existential } \\
\text { thinking }\end{array}$ & $\begin{array}{l}\text { CET1: I often ask the question and reflect on the characteristics of reality. } \\
\text { CET2: I use the time to reflect on the reason for my existence. } \\
\text { CET3: I can deeply reflect on something that happened after death. } \\
\text { CET4: I have developed my theory about things like life, death, reality, and existence. } \\
\text { CET5: I often reflect on the meaning of events in my life. } \\
\text { CET6: I often contemplate the relationship between humans and the whole universe } \\
\text { CET7: I think about unlimited power. }\end{array}$ \\
\hline $\begin{array}{l}\text { Personal meaning } \\
\text { production }\end{array}$ & $\begin{array}{l}\text { PMP1: I can find meaning and purpose in life so that it helps me adapt to stressful situations. } \\
\text { PMP2: I can define goals or reasons for my life. } \\
\text { PMP3: When I failed, I was still able to find meaning in my failure. } \\
\text { PMP4: I can make decisions according to the purpose of my life. } \\
\text { PMP5: I can find meaning and purpose in my daily experience. }\end{array}$ \\
\hline $\begin{array}{l}\text { Transcendental } \\
\text { awareness }\end{array}$ & $\begin{array}{l}\text { TA1: I recognize aspects of myself better than my physique. } \\
\text { TA2: I easily feel beyond tangible items. } \\
\text { TA3: I realize a deeper relationship between me and others exists. } \\
\text { TA4: I define myself deeper than my physique. } \\
\text { TA5: I have a high awareness of non-physical aspects of life. } \\
\text { TA6: I recognize the quality of people more meaningful than their body, personality, or } \\
\text { emotion. } \\
\text { TA7: Recognizing aspects of non-physical life helps me concentrate. }\end{array}$ \\
\hline $\begin{array}{l}\text { Conscious } \\
\text { expansion }\end{array}$ & $\begin{array}{l}\text { CSE1: I can achieve a high level of consciousness. } \\
\text { CSE2: I can control myself when entering a higher level of consciousness. } \\
\text { CSE3: I can freely move between levels of consciousness } \\
\text { CSE4: I often see problems and choices clearly when a high awareness exists. } \\
\text { CSE5: I can develop techniques to enter higher awareness. }\end{array}$ \\
\hline
\end{tabular}

Source: Adopted from Anwar and Osman-Gani (2015)

The fourth variable is the lecturer's performance. We define it as the success of the lecturer to perform the activities related to research, community service, and teaching. Furthermore, three aspects become the dimension of the performance. The indicators used in this study for each dimension refer to the relevant content of the accreditation instrument version 4 for the study program. For the research performance dimension, the indicators are as follows.

1. I can publish my research results in reputable international and national journals (RP1)

2. I can publish my research results in the proceeding of international and national conferences or seminars (RP2).

3. I can publish my research results in international and national media that can be accessed by the public (RP3).

4. I can get external funds from abroad or domestic to finance the research (RP4).

5. I can obtain an intellectual property right based on the results of my research (RP5).

6. I can produce books with ISBN based on the results of my research (RP6).

For the community service performance dimension, the indicators are as follows.

1. I can publish the activity related to the service for the community in the related journals and proceedings (CSP1)

2. I can obtain an intellectual property right based on the activities of the service for the community (CSP2).

3. I can obtain an intellectual property right based on the activities of the service for the community (CSP3).

4. I can produce books with ISBN based on the results of the service community (CSP4).

For the teaching performance dimension, the indicators are as follows.

1. I can mix the results of my research into the learning materials for the students (TP1).

2. I can mix the results of my service community into the learning materials for the students (TP2). 


\subsection{Validity and Reliability Test}

Although the instruments are already designed based on existing literature, testing the data validity and reliability is still vital. The validity and reliability test intends to prove the accuracy and consistency of respondents' answers, respectively.

- This research uses confirmatory factor analysis (CFA) as the validity test, by comparing the loading factor value of each indicator with the 0.5 . If its value exceeds 0.5 , the answer of respondents is valid. If it has a value below 0.5 , it should be removed (Sholihin \& Ratmono, 2013).

- This research utilizes the Cronbach Alpha (CA) analysis as the reliability test after all respondents' answers of indicators are valid. This analysis is conducted by comparing the CA value with 0.7 . A collection of convincing indicators is reliable if the CA is higher than 0.7 (Ghozali, 2016).

\subsection{Data Analysis Method}

Examining the effect of motivation (M), emotional intelligence (EI), and spiritual intelligence (SI) on lecturer performance (LP) requires for a method variance-based structural equation model to analyze data. This is because these variables are not directly observed, and the number of respondents is between 30 and 100 (Ghozali, 2014). Additionally, this model is exhibited in equation two.

$$
\mathrm{LP}=\beta_{0}+\gamma_{1} \cdot \mathrm{M}+\gamma_{2} \mathrm{EI}+\gamma_{3} . \mathrm{SI}+\zeta
$$

\section{Result and discussion}

\subsection{The Statistics of the Demographic Characteristics}

The statistic used is the frequency to capture the total lecturers categorized by gender, functional position, the study field, working duration, work status, academic degree. Table 4 presents the number of lecturers by gender. Of the 100, 66 females $(66 \%)$ and 34 males (34\%) participate in this survey.

Table 4: The Total Lecturers categorized by gender

\begin{tabular}{|c|c|c|}
\hline Gender & The number of lecturers & Percentage \\
\hline Male & 34 & $34 \%$ \\
\hline Female & 66 & $66 \%$ \\
\hline Total & 100 & $100 \%$ \\
\hline
\end{tabular}

Source: Processed Survey Data

Table 5 exhibits the number of lecturers joining this survey, categorized by their functional position. The number of the expert assistants is $25(25 \%)$, the senior lecturer is $45 \%$, the associate professors are $27(27 \%)$, and there are 3 professors $(3 \%)$.

Table 5: The Total Lecturers categorized by Functional Position

\begin{tabular}{|c|c|c|}
\hline Functional Position & The number of lecturers & Percentage \\
\hline Expert Assistant & 25 & $25 \%$ \\
\hline Senior Lecturer & 45 & $45 \%$ \\
\hline Associate Professor & 27 & $27 \%$ \\
\hline Professors & 3 & $3 \%$ \\
\hline Total & 100 & $100 \%$ \\
\hline
\end{tabular}

Source: Processed Survey Data

Table 6 illustrates the number of lecturers categorized by the field of their study. This table informs that the number of lecturers from the management field is 88 , from the accounting field is 2 , from the business administration field and industrial engineering field is 2 . There is one lecturer from Islamic economics and finance field, the economics of development field, and information system field, respectively.

Table 6: The total number of lecturers categorized by the field of study

\begin{tabular}{|l|c|c|}
\hline \multicolumn{1}{|c|}{ The Field of Study } & The number of lecturers & Percentage \\
\hline Business administration & 2 & $2 \%$ \\
\hline
\end{tabular}


Rosemarie S. Njotoprajitno, Nur, Rully Arlan Tjahjadi, Bram Hadianto, Andre Sunjaya

The Effect of Motivation, Emotional and Spiritual Intelligence on Lecturer Performance

\begin{tabular}{|l|c|c|}
\hline Accounting & 5 & $5 \%$ \\
\hline Islamic economics and finance & 1 & $1 \%$ \\
\hline Economics of development & 1 & $1 \%$ \\
\hline Management & 88 & $88 \%$ \\
\hline Information system & 1 & $1 \%$ \\
\hline Industrial engineering & 2 & $2 \%$ \\
\hline \multicolumn{1}{|c|}{ Total } & 100 & $100 \%$ \\
\hline
\end{tabular}

Source: Processed Survey Data

Table 7 displays the number of lecturers by their tenure. This table shows that the number of lecturers having a tenure less than 10 years is 19 , between 10 and 20 is 44, between 21 and 30 is 30, over 30 is 7 .

Table 7: The number of lecturers categorized by the working duration

\begin{tabular}{|c|c|c|}
\hline Working duration & The number of lecturers & Percentage \\
\hline$<10$ Year & 19 & $19 \%$ \\
\hline $10-20$ Years & 44 & $44 \%$ \\
\hline $21-30$ Years & 30 & $30 \%$ \\
\hline$>30$ Years & 7 & $7 \%$ \\
\hline Total & 100 & $100 \%$ \\
\hline
\end{tabular}

Source: Processed Survey Data

Table 8 shows the number of lecturers categorized by their status. This table shows that the number of lecturers without and with the additional managerial assignment is 53 and 47, respectively.

Table 8: The number of lecturers categorized by the work status

\begin{tabular}{|c|c|c|}
\hline \multicolumn{1}{|c|}{ Status of work } & The number of lecturers & Percentage \\
\hline Lecturer without the additional managerial assignment & 53 & $53 \%$ \\
\hline Lecturer with additional managerial assignments & 47 & $47 \%$ \\
\hline Total & 100 & $100 \%$ \\
\hline
\end{tabular}

Source: Processed Survey Data

Table 9 displays the number of lecturers categorized by academic degrees of master of 54 and doctor of 46, respectively.

Table 9: The number of lecturers categorized by the academic degree

\begin{tabular}{|c|c|c|}
\hline Academic Degree & The number of respondents & Percentage \\
\hline Master & 54 & $54 \%$ \\
\hline Doctor & 46 & $46 \%$ \\
\hline Total & 100 & $100 \%$ \\
\hline
\end{tabular}

Source: Processed Survey Data

\subsection{The Output of Validity and Reliability Test and Interpretation}

This study uses confirmatory factor analysis (CFA) to test the data validity. For motivation, the first result is illustrated in Table 10A. As seen in this table, M6 is the invalid indicator because the loading factor value is 0.298 , lower than 0.5 . Hence, removing M6 is essential.

Table 10A: The beginning CFA result: The Loading Factor Values of Motivation Indicators

\begin{tabular}{|c|c|c|c|c|c|}
\hline Indicator & $\begin{array}{c}\text { Loading } \\
\text { factor }\end{array}$ & Interpretation & Indicator & $\begin{array}{c}\text { Loading } \\
\text { factor }\end{array}$ & Interpretation \\
\hline M1 & 0.613 & Valid & M6 & 0.298 & Invalid \\
\hline
\end{tabular}


Table 10A: The beginning CFA result: The Loading Factor Values of Motivation Indicators

\begin{tabular}{|c|c|c|c|c|c|}
\hline Indicator & $\begin{array}{c}\text { Loading } \\
\text { factor }\end{array}$ & Interpretation & Indicator & $\begin{array}{c}\text { Loading } \\
\text { factor }\end{array}$ & Interpretation \\
\hline M2 & 0.729 & Valid & M7 & 0.672 & Valid \\
\hline M3 & 0.581 & Valid & M8 & 0.665 & Valid \\
\hline M4 & 0.740 & Valid & M9 & 0.645 & Valid \\
\hline M5 & 0.664 & Valid & M10 & 0.749 & Valid \\
\hline
\end{tabular}

Source: Modified Warp PLS Output

After removing M6, CFA was conducted again, and the result is in Table 10B. As seen in this table, all the indicators are valid because all the loading factors are above 0.5 .

Table 10B: The final CFA Result: The Loading Factor Values of Motivation Indicators

\begin{tabular}{|c|c|c|c|c|c|}
\hline Indicator & $\begin{array}{c}\text { Loading } \\
\text { factor }\end{array}$ & Interpretation & Indicator & $\begin{array}{c}\text { Loading } \\
\text { factor }\end{array}$ & Interpretation \\
\hline M1 & 0.629 & Valid & M7 & 0.659 & Valid \\
\hline M2 & 0.739 & Valid & M8 & 0.648 & Valid \\
\hline M3 & 0.588 & Valid & M9 & 0.649 & Valid \\
\hline M4 & 0.748 & Valid & M10 & 0.734 & Valid \\
\hline M5 & 0.678 & Valid & & & \\
\hline
\end{tabular}

Source: Modified Warp PLS Output

For self-awareness as the first dimension of emotional intelligence, SA3, SA4, SA7, and SA10 are the invalid indicators because their loading factor values are $0.257,0.268,0.476,0.426$, respectively, lower than 0.5 (see Panel A of Table 11A). For motivation as the second dimension of motivation, MOT1 and MOT6 are invalid because their loading factors are 0.319 and 0.064 , respectively, lower than 0.5 (see Panel B of Table 11A). For empathy and social skill as the third and fourth dimensions, all the indicators are valid because these loading factor values are higher than 0.5 (see Panel C and D of Table 11A).

Table 11A: The beginning result of CFA: The Loading Factor Values of Self-Awareness, Self-Control, Motivation, Empathy, and Social Skill Indicators

\begin{tabular}{|c|c|c|c|c|c|}
\hline \multicolumn{7}{|l|}{ Panel A. Dimension of self-awareness } \\
\hline Indicator & Loading factor & Interpretation & Indicator & Loading factor & Interpretation \\
\hline SA1 & 0.589 & Valid & SA6 & 0.776 & Valid \\
\hline SA2 & 0.660 & Valid & SA7 & 0.476 & Invalid \\
\hline SA3 & 0.257 & Invalid & SA8 & 0.730 & Valid \\
\hline SA4 & 0.268 & Invalid & SA9 & 0.766 & Valid \\
\hline SA5 & 0.730 & Valid & SA10 & 0.426 & Invalid \\
\hline Panel B. Dimension of self-control & & & & \\
\hline Indicator & Loading factor & Interpretation & Indicator & Loading factor & Interpretation \\
\hline SC1 & 0.787 & Valid & SC6 & 0.865 & Valid \\
\hline SC2 & 0.624 & Valid & SC7 & 0.629 & Valid \\
\hline SC3 & 0.708 & Valid & SC8 & 0.761 & Valid \\
\hline SC4 & 0.817 & Valid & SC9 & 0.805 & Valid \\
\hline SC5 & 0.793 & Valid & SC10 & 0.683 & Valid \\
\hline Panel C. Dimension of motivation & & & & \\
\hline
\end{tabular}


Rosemarie S. Njotoprajitno, Nur, Rully Arlan Tjahjadi, Bram Hadianto, Andre Sunjaya

The Effect of Motivation, Emotional and Spiritual Intelligence on Lecturer Performance

\begin{tabular}{|c|c|c|c|c|c|}
\hline Indicator & Loading factor & Interpretation & Indicator & Loading factor & Interpretation \\
\hline MOT1 & 0.319 & Invalid & MOT6 & 0.064 & Invalid \\
\hline MOT2 & 0.660 & Valid & MOT7 & 0.740 & Valid \\
\hline MOT3 & 0.774 & Valid & MOT8 & 0.560 & Valid \\
\hline MOT4 & 0.670 & Valid & MOT9 & 0.830 & Valid \\
\hline MOT5 & 0.831 & Valid & MOT10 & 0.677 & Valid \\
\hline
\end{tabular}

Panel D. The Dimension of Empathy

\begin{tabular}{|c|c|c|c|c|c|}
\hline Indicator & Loading factor & Interpretation & Indicator & Loading factor & Interpretation \\
\hline E1 & 0.583 & Valid & E6 & 0.739 & Valid \\
\hline E2 & 0.622 & Valid & E7 & 0.678 & Valid \\
\hline E3 & 0.645 & Valid & E8 & 0.688 & Valid \\
\hline E4 & 0.763 & Valid & E9 & 0.789 & Valid \\
\hline E5 & 0.680 & Valid & E10 & 0.757 & Valid \\
\hline
\end{tabular}

Panel E. The Dimension of Social Skill

\begin{tabular}{|c|r|c|c|c|c|}
\hline Indicator & Loading factor & Interpretation & Indicator & Loading factor & Interpretation \\
\hline SS1 & 0.777 & Valid & SS5 & 0.817 & Valid \\
\hline SS2 & 0.758 & Valid & SS6 & 0.615 & Valid \\
\hline SS3 & 0.585 & Valid & SS7 & 0.584 & Valid \\
\hline SS4 & 0.864 & Valid & & & \\
\hline
\end{tabular}

Source: Modified Warp PLS Output

After eliminating the invalid indicators of SA3, SA4, SA7, SA10, MOT1, and MOT6, the CFA is conducted again, and the result is shown in Table 11B. As illustrated by this table, all the indicators of each dimension of emotional intelligence are valid since these loading factor values are higher than 0.5 .

Table 11B: The final result of CFA: The Loading Factor Values of Self-Awareness and Motivation

\begin{tabular}{|c|c|c|c|c|c|}
\hline \multicolumn{6}{|c|}{ Panel A. Dimension of self-awareness } \\
\hline Indicator & Loading factor & Interpretation & Indicator & Loading factor & Interpretation \\
\hline SA1 & 0.635 & Valid & SA6 & 0.788 & Valid \\
\hline SA2 & 0.730 & Valid & SA8 & 0.726 & Valid \\
\hline SA5 & 0.762 & Valid & SA9 & 0.741 & Valid \\
\hline \multicolumn{6}{|c|}{ Panel B. Dimension of motivation } \\
\hline Indicator & Loading factor & Interpretation & Indicator & Loading factor & Interpretation \\
\hline MOT2 & 0.668 & Valid & MOT7 & 0.741 & Valid \\
\hline MOT3 & 0.776 & Valid & MOT8 & 0.553 & Valid \\
\hline MOT4 & 0.687 & Valid & MOT9 & 0.824 & Valid \\
\hline MOT5 & 0.844 & Valid & MOT10 & 0.662 & Valid \\
\hline
\end{tabular}

Source: Modified Warp PLS Output

Once the indicators are valid, determining the validity status of each dimension, reflecting emotional intelligence is required. The result is listed in Table 11C. Dimensions are valid because their loading factor is higher than 0.5.

Table 11C: The final result of CFA: The Loading Factor Value of the Emotional Intelligence Dimensions

\begin{tabular}{|l|c|c|}
\hline Dimension & Loading Factor & Interpretation \\
\hline Self-awareness & 0.735 & Valid \\
\hline Self-control & 0.875 & Valid \\
\hline
\end{tabular}


Rosemarie S. Njotoprajitno, Nur, Rully Arlan Tjahjadi, Bram Hadianto, Andre Sunjaya

The Effect of Motivation, Emotional and Spiritual Intelligence on Lecturer Performance

\begin{tabular}{|l|c|c|}
\hline Dimension & Loading Factor & Interpretation \\
\hline Motivation & 0.883 & Valid \\
\hline Empathy & 0.824 & Valid \\
\hline Social skill & 0.870 & Valid \\
\hline
\end{tabular}

Source: Modified Warp PLS Output

Table 12A shows the loading factor values of the indicators of the dimensions of spiritual intelligence. Because these values are higher than 0.5 , the validity test on these indicators is achieved.

Table 12A: The CFA result: The Loading Factor Indicators Values of Dimensions of Spiritual Intelligence

\begin{tabular}{|c|c|c|c|c|c|}
\hline \multicolumn{2}{|c|}{ Panel A. Dimension of Critical Existential Thinking } & \multicolumn{3}{c|}{ Panel C. Dimension of transcendental awareness } \\
\hline Indicator & Loading factor & Interpretation & Indicator & Loading factor & Interpretation \\
\hline CET1 & 0.859 & Valid & TA1 & 0.765 & Valid \\
\hline CET2 & 0.881 & Valid & TA2 & 0.747 & Valid \\
\hline CET3 & 0.868 & Valid & TA3 & 0.844 & Valid \\
\hline CET4 & 0.650 & Valid & TA4 & 0.856 & Valid \\
\hline CET5 & 0.853 & Valid & TA5 & 0.887 & Valid \\
\hline CET6 & 0.932 & Valid & TA6 & 0.825 & Valid \\
\hline CET7 & 0.813 & Valid & TA7 & 0.869 & Valid \\
\hline Panel B. Dimension of personal meaning production & Panel D. Dimension of conscious state expansion \\
\hline Indicator & Loading factor & Interpretation & Indicator & Loading factor & Interpretation \\
\hline PMP1 & 0.826 & Valid & CSE1 & 0.822 & Valid \\
\hline PMP2 & 0.905 & Valid & CSE2 & 0.918 & Valid \\
\hline PMP3 & 0.896 & Valid & CSE3 & 0.946 & Valid \\
\hline PMP4 & 0.865 & Valid & CSE4 & 0.909 & Valid \\
\hline PMP5 & 0.887 & Valid & CSE5 & 0.927 & Valid \\
\hline
\end{tabular}

Source: Modified Warp PLS Output

After determining the validity of all indicators, deciding the validity status of each dimension, reflecting spiritual intelligence is essential. Results are illustrated in Table 12B. In this table, the loading factor value exceeds 0.5 . Therefore, the five dimensions reflecting spiritual intelligence are valid.

Table 12B: Loading Factor Value of Dimensions of Spiritual Intelligence

\begin{tabular}{|l|c|c|}
\hline Dimension & Loading Factor & Interpretation \\
\hline Critical existential thinking & 0.814 & Valid \\
\hline Personal meaning production & 0.761 & Valid \\
\hline Transcendental awareness & 0.855 & Valid \\
\hline Conscious state expansion & 0.815 & Valid \\
\hline
\end{tabular}

Source: Modified Warp PLS Output

Table 13A shows the loading factor values of the dimensions of lecturer performance. Since these values are higher than 0.5 , the validity test on these dimensions gets achieved.

Table 13A: The CFA result: The Loading Factor Indicator Values of Dimensions of Lecturer Performance

\begin{tabular}{|c|c|c|}
\hline \multicolumn{3}{|c|}{ Panel A. Dimension of research performance } \\
\hline Indicator & Loading factor & Interpretation \\
\hline RP1 & 0.612 & Valid \\
\hline RP2 & 0.596 & Valid \\
\hline RP3 & 0.638 & Valid \\
\hline RP4 & 0.728 & Valid \\
\hline
\end{tabular}


Table 13A: The CFA result: The Loading Factor Indicator Values of Dimensions of Lecturer Performance

\begin{tabular}{|c|c|c|}
\hline RP5 & 0.751 & Valid \\
\hline RP6 & 0.731 & Valid \\
\hline \multicolumn{2}{|c|}{ Panel B. Dimension of community service performance } \\
\hline Indicator & Loading factor & Interpretation \\
\hline CSP1 & 0.830 & Valid \\
\hline CSP2 & 0.841 & Valid \\
\hline CSP3 & 0.863 & Valid \\
\hline CSP4 & 0.854 & Valid \\
\hline Panel C. Dimension of teaching performance & Interpretation \\
\hline Indicator & Loading factor & Valid \\
\hline TP1 & 0.947 & Valid \\
\hline TP2 & 0.947 &
\end{tabular}

Source: Modified Warp PLS Output

Once all the indicators are valid, determining the validity status of each dimension, reflecting lecturer performance is vital. Results are shown in Table 13B. Because these values are higher than 0.5 , the validity test on these dimensions gets achieved.

Table 13B: Loading Factor Value of Dimensions of Lecturer Performance

\begin{tabular}{|l|c|c|}
\hline \multicolumn{1}{|c|}{ Dimension } & Loading Factor & Interpretation \\
\hline Research Performance & 0.895 & Valid \\
\hline Community Service Performance & 0.853 & Valid \\
\hline Teaching Performance & 0.675 & Valid \\
\hline
\end{tabular}

Source: Modified Warp PLS Output

This study uses the Cronbach Alpha (CA) analysis to determine the reliability of the valid indicators for motivation and dimension of emotional and spiritual intelligence, as well as lecturer performance. The result is in Table 14. Because all coefficients of CA are higher than 0.7 , the reliability test stand reached.

Table 14: Cronbach Alpha's Coefficient of The Valid Indicators

\begin{tabular}{|l|c|c|l|c|}
\hline \multicolumn{1}{|c|}{$\begin{array}{c}\text { Latent Variable/ } \\
\text { Dimension }\end{array}$} & $\begin{array}{c}\text { Measurement } \\
\text { Status }\end{array}$ & $\begin{array}{c}\text { Total valid } \\
\text { Indicators }\end{array}$ & \multicolumn{1}{|c|}{ The name of valid indicators } & $\begin{array}{c}\text { Cronbach } \\
\text { Alpha }\end{array}$ \\
\hline Motivation & $\begin{array}{c}\text { Latent } \\
\text { variable }\end{array}$ & 9 & $\begin{array}{l}\text { M1, M2, M3, M4, M5, M7, M8, M9, } \\
\text { M10 }\end{array}$ & 0.851 \\
\hline $\begin{array}{l}\text { Emotional intelligence } \\
\text { (EI)/self-awareness }\end{array}$ & Dimension & 6 & SA1, SA2, SA5, SA6, SA8, SA9 & 0.825 \\
\hline EI/self- control & Dimension & 10 & $\begin{array}{l}\text { SC1, SC, SC3, SC4, SC5, SC6, SC7, } \\
\text { SC8, SC9, SC10 }\end{array}$ & 0.912 \\
\hline EI/motivation & Dimension & & $\begin{array}{l}\text { MOT2, MOT3, MOT4, MOT5, } \\
\text { MOT7, MOT8, MOT9, MOT10 }\end{array}$ & 0.867 \\
\hline EI/ empathy & Dimension & 7 & $\begin{array}{l}\text { E1, E2, E3, E4, E5, E6, } \\
\text { S7, E8, E9, E10 }\end{array}$ & 0.881 \\
\hline EI/social skill & Dimension & 7 & $\begin{array}{l}\text { CET1, CET2, CET3, CET4, CET5, } \\
\text { CET6, CET7 }\end{array}$ & 0.841 \\
\hline $\begin{array}{l}\text { Spiritual intelligence (SI)/ } \\
\text { critical existential thinking }\end{array}$ & \multicolumn{2}{|l}{0.929} \\
\hline
\end{tabular}


Table 14: Cronbach Alpha's Coefficient of The Valid Indicators

\begin{tabular}{|l|c|c|l|c|}
\hline \multicolumn{1}{|c|}{$\begin{array}{c}\text { Latent Variable/ } \\
\text { Dimension }\end{array}$} & $\begin{array}{c}\text { Measurement } \\
\text { Status }\end{array}$ & $\begin{array}{c}\text { Total valid } \\
\text { Indicators }\end{array}$ & \multicolumn{1}{|c|}{ The name of valid indicators } & $\begin{array}{c}\text { Cronbach } \\
\text { Alpha }\end{array}$ \\
\hline $\begin{array}{l}\text { SI/personal meaning } \\
\text { production }\end{array}$ & Dimension & 5 & PMP1, PMP2, PMP3, PMP4, PMP5 & 0.924 \\
\hline SI/ transcendental awareness & Dimension & 7 & $\begin{array}{l}\text { TA1, TA2, TA3, TA4, TA5, TA6, } \\
\text { TA7 }\end{array}$ & 0.923 \\
\hline SI/ conscious state expansion & Dimension & 5 & CSE1, CSE2, CSE3, CSE4, CSE5 & 0.944 \\
\hline $\begin{array}{l}\text { Lecturer Performance (LP)/ } \\
\text { Research Performance }\end{array}$ & Dimension \\
\hline $\begin{array}{l}\text { LP/ Community Service } \\
\text { Performance }\end{array}$ & Dimension & 4 & RP1, RP2, RP3, RP4, RP5, RP6 & 0.764 \\
\hline LP/ Teaching Performance & Dimension & 2 & TP1, TP2 & 0.869 \\
\hline
\end{tabular}

Source: Modified Warp PLS Output

\subsection{The Estimation Result of Structural Equation Model}

After testing the validity and reliability of the data, estimating the variance-based structural equation model (SEM) is the subsequent step, and the result is in Table 15.

Table 15: The Estimation Result of Variance-based SEM for The Effect of Motivation, Emotional and Spiritual Intelligence on Lecturer Performance

\begin{tabular}{lcccc}
\hline $\begin{array}{c}\text { The determinant of lecturer } \\
\text { performance }\end{array}$ & $\begin{array}{c}\text { Path } \\
\text { Coefficient }\end{array}$ & $\begin{array}{c}\text { Standard } \\
\text { error }\end{array}$ & t-statistic & $\begin{array}{c}\text { Probability } \\
\text { Value }\end{array}$ \\
\hline Motivation & 0.140 & 0.140 & 1.000 & 0.160 \\
Emotional Intelligence & 0.361 & 0.141 & 2.560 & 0.006 \\
Spiritual Intelligence & 0.160 & 0.137 & 1.168 & 0.122 \\
\hline
\end{tabular}

Source: Modified Warp PLS Output

\subsection{The Test Result of the Hypotheses}

The first research hypothesis states that motivation has a positive effect on lecturer performance; it becomes the first alternative hypothesis. Moreover, we test the null hypothesis by comparing the probability value of t-statistic for motivation with a significance level $(\alpha)$ of $5 \%$. In Table 15 , this value is 0.160 . Since this value is higher than $\alpha$, the null hypothesis stating motivation does not affect the lecturer's performance is accepted.

The second research hypothesis states that emotional intelligence has a positive effect on lecturer performance; it becomes the second alternative hypothesis. Moreover, we tested the null hypothesis by comparing the probability value of t-statistic for emotional intelligence with a significance level $(\alpha)$ of $5 \%$. In Table 15 , this value is 0.006 . Since this value is lower than $\alpha$, the null hypothesis is rejected. Instead, the alternative hypothesis is accepted.

The third research hypothesis states that spiritual intelligence has a positive effect on lecturer performance. Moreover, we test the null hypothesis by comparing the probability value of t-statistic for spiritual intelligence with a significance level $(\alpha)$ of $5 \%$. In Table 15, the probability value is 0.122 . Since this value is higher than $\alpha$, the null hypothesis, declaring spiritual intelligence does not affect the lecturer's performance, is recognized.

\subsection{Discussion}

In this research, motivation does not have a positive effect on lecturer performance. Even when lecturers are well encouraged, this does not impact their performance. According to Robescu and Iancu (2016), this is due to the difficulty of tasks have to accomplish. In the context of this study, the responsibilities of lecturers encompass publishing their articles in a reputable international journal and resulting in useful outcomes based on their research. 
Moreover, this research displays that emotional intelligence has a positive effect on the lecturers' performance. This intelligence enables lecturers to collaborate when they teach a team of students and design the contents of subjects for improving the curriculum, execute the research and service community activity and publish their results in the related average journal to get the various forms of intellectual property rights. Therefore, this research confirms the study of Muttaqiyathun (2010), Faitullah (2014), Anwar (2017), and Makkasau (2018).

Furthermore, this research shows that spiritual intelligence does not affect lecturer performance. This means that spiritual intelligence cannot contribute to working performance. Therefore, this research affirms the study result of Haryono et al. (2018).

\section{Conclusion}

The goal of this research is to examine and analyze the impact of motivation, emotional, and spiritual intelligence on lecturer performance by SEM based on variance. Based on the executed analysis, this study implies two things.

1. Motivation and spiritual intelligence do not affect lecturer performance.

2. Emotional intelligence has a positive effect on lecturer performance.

Evidence has both practical and theoretical suggestions.

- As a practical implication, achieving an excellent performance requires the training of emotional intelligence. Therefore, higher education institutions can facilitate this training for their lecturers to increase the ability to control their emotions and to cooperate in the teamwork.

- As a theoretical implication, the next researchers can do two things. Firstly, employing the other determinants of lecturer performance like intellectual intelligence, compensation, work environment, leadership, organizational citizenship behaviour, and stress. Secondly, treating spiritual intelligence as a moderating variable of the causal relationship between stress and performance.

\section{References}

- Ali, A., Bin, L. Z., Piang, H. J., and Ali, Z. (2014). The Impact of Motivation on the Employee Performance and Job Satisfaction in IT Park (Software House) Sector of Peshawar, Pakistan. International Journal of Academic Research in Business and Social Sciences, 6(9), 297-310. Crossref

- Anwar, M. (2017). Pengaruh Motivasi, Kecerdasan Emosional, dan Kepemimpinan Transformasional terhadap Kinerja Melalui Kepuasan Kerja Dosen Perguruan Tinggi Swasta di Banjarmasin. Dinamika Ekonomi Jurnal Ekonomi dan Bisnis, 10(2), 147-166.

- Bestyasamala, E. (2018). The Influence of Emotional Intelligence and Organizational Citizenship Behavior Towards Officer Performance with the Organization and Religiosity as A Moderating Variable (Study on the Employee of the Education and Culture Departement in Demak). International Jurnal of Islamic Business Ethics, 3(1), 423-436. Crossref

- Faitullah. (2014). Pengaruh Kompetensi, Motivasi dan Kecerdasan Emosi Terhadap Kinerja Dosen di PerguruanTinggi Swasta Kopertis Wilayah II (Studi Kasus pada Univeristas Binadarma dan Universitas Tridinanti). Jurnal Manajemen dan Bisnis Sriwijaya, 12(4), 275-300.

- Gabčanová. (2011). The Employees - The Most Important Asset. Human Resources Management and Ergonomics, 5(1), 1-12.

- Ghozali, I. (2014). Model Persamaan Struktural: Konsep dan Aplikasi dengan Program AMOS 22.0. Semarang: Badan Penerbit Universitas Diponegoro.

- Ghozali, I. (2016). Aplikasi Analisis Multivariate dengan Program IBM SPSS 23. Semarang: Badan Penerbit Universitas Diponegoro.

- Gibson, J. L., Ivancevich, J. M., Donnelly, J. H., and Konopaske, R. (2012). Organizations: Behavior, Structure, Processes. New York: McGraw-Hill.

- Gunu, U., and Oladepo, R. O. (2014). Impact of Emotional Intelligence on Employees' Performance and Organizational Commitment: A Case Study of Dangote Flour Mills Workers. University of Mauritius Research Journal, 20, 1-32. 
- Hanafi, R. (2014). Spiritual Intelligence, Emotional Intelligence, Emotional Intelligence, and Auditor's Performance. Jurnal Akuntansi dan Auditing Indonesia, 14(1), 29-40.

- Haryono, S., Rosadi, F., and MdSaad, M. S. (2018). Effects of Emotional and Spiritual Intelligence on Job Performance among Temporary Nurses at Abdul Riva's Regional General Hospital, Berau District, East Kalimantan Province, Indonesia. Management Issues in Healthcare System, 4, 42-54. Crossref

- Kimiyayi, M., and Daryaee, S. (2016). Relationship between spiritual intelligence, emotional intelligence with occupational performance the guidance school teachers' occupational performance in Shiraz educational system organization (first area). International Journal of Humanities and Cultural Studies, 3(2), 981-999.

- Makkasau, S. (2018). Pengaruh Kecerdasan Intelektual, Emosional, dan Spiritual terhadap Kinerja Dosen pada Perguran Tinggi Kesehatan di Kota Palopo. Jurnal Voice of Midwifery, 8(1), 710-722. Crossref

- Muogbo, U. S. (2013). The Influence of Motivation on Employees' Performance: A Study of Some Selected Firms in Anambra State. AFRREV: An International Journal of Arts and Humanities, 2(3), 134-151.

- Muttaqiyathun, A. (2010). Pengaruh Kecerdasan Emosional, Kecerdasan Intelektual, dan Kecerdasan Spiritual terhadap Kinerja Dosen. Ekonomika-Bisnis, 2(2), 395-408.

- Narasuci, W., Setiawan, M., and Noermijati. (2018). Effect of Work Environment on Lecturer Performance Mediated by Work Motivation and Job Satisfaction. Journal of Applied Management, 16, 645-653. Crossref

- Noermijati. (2013). Kajian tentang Aktualisasi Teori Herzberg, Kepuasan Kerja dan Kinerja Spiritual Manajer Operasional. Malang: Universitas Brawijaya Press.

- Noermijati. (2015). Peran Kepemimpinan Transformasional dan Motivasi terhadap Kinerja Karyawan dengan Moderasi Masa Kerja. Jurnal Keuangan dan Perbankan, 19(2), 326-335.

- Nur'aeni. (2011). Pengaruh Motivasi, Kompetensi, dan Komitmen terhadap Kinerja Dosen Perguruan Tinggi Swasta di Kopertis Wilayah III Palembang (Survey pada Perguruan Tinggi Swasta di Kopertis Wilayah II Palembang). Jurnal Manajemen dan Bisnis, 1(2), 101-129. Crossref

- Othman, A. K., Abas, M. K., and Ishak, M. S. (2017). The Moderating Role of Spiritual Intelligence on The Relationship Between Job Stress and Job Performance of Employees in A Banking Sector. Journal of Islamic Management Studies, 1(1), 89-103.

- Perwita, A. D., Nurmalina, R., and Affandi, J. (2016). Pengaruh Faktor-Faktor Motivasi terhadap Kinerja Pegawai di PT Bank BNI Syariah Kantor Cabang Jakarta Barat dan Bogor. Jurnal Aplikasi Bisnis dan Manajemen, 3(1), 102112. Crossref

- Pramudyo, A. (2010). Analisis Faktor-Faktor yang mempengaruhi Kinerja Dosen Negeri pada Kopertis Wilayah V Yogyakarta. Jurnal Bisnis: Teori dan Implementasi, 1(1), 1-11.

- Rina, and Kusuma, A. H. (2017). Pengaruh Kompetensi, Budaya Organisasi, dan Motivasi terhadap Kinerja Dosen Perguruan Tinggi Swasta di Kota Makassar. Jurnal Riset Unibos Makassar, 3(8), 88-100.

- Rishipal, and Manish. (2013). Performance Management and Employee Loyalty. Global Journal of Management and Business Research, 13(3), 23-26.

- Robescu, O., and Iancu, A. (2016). The Effects of Motivation on Employees Performance in Organizations. Valahian Journal of Economic Studies Sciendo, 7(2), 49-56. Crossref

- Sholihin, M., and Ratmono, D. (2013). Analisis SEM-PLS dengan WarpPLS 3.0. Yogyakarta: Penerbit ANDI.

- Sugiyanto, C., Nahartyo, E., Misra, F., Bastian, I., Hartono, J., Saputro, J. A., Sholihin, M., Sivilokonom, N. I., Almahendra, R., Winardi, R. D., Rostiani, R., Warsono, S., Ciptono, W. S., Widyaningsih, Y. A. (2018). Strategi Penelitian Bisnis. Yogyakarta: Penerbit ANDI.

- Suliyanto. (2009). Metode Riset Bisnis. Yogyakarta: Penerbit ANDI.

- Taruno, F. X., Thoyib, A., Zain, D., and Rahayu, M. (2012). Pengaruh Gaya Kepemimpinan terhadap Kinerja Dosen dengan Kepuasan Kerja dan Motivasi Kerja sebagai Mediator (Studi pada Perguruan Tinggi Swasta di Jayapura). Jurnal Aplikasi Manajemen, 10(3), 495-509.

- Tjun, L. T., Setiawan, S., and Setiana, S. (2009). Pengaruh Kecerdasan Emosional Terhadap Pemahaman Akuntansi Dilihat dari Perspektif Gender. Jurnal Akuntansi, 1(2), 101-118.

- Trisnaningsih, S. (2011). Faktor-Faktor yang mempengaruhi Kinerja Dosen Akuntansi. Jurnal Akuntansi and Auditing, 8(1), 83-94.

- Vosloban, R. I. (2012). The Influence of the Employee's Performance on the company's growth - a managerial perspective. Procedia Economics and Finance, 3, 660-665. Crossref

- Zahraini, Z. (2014). Kinerja Dosen dalam Meningkatkan Kempuan Akademik (Hardskill) dan Penguasaan Keterampilan (Softskill) pada Mahasiswa PKK FKIP Unsyiah. Jurnal Ilmiah Didaktika, 14(2), 350-367. Crossref 